\title{
The Coercive Power of Shared Values
}

\section{Robert Ayson}

\section{Revised Manuscript Submitted to Political Science,}

(February 2019)

\section{Abstract}

While values often evoke noble aims, groups of countries sometimes use statements about the values they share to coerce others. Allies coordinate around their shared values talk to apply reputational pressure on adversaries. Examples include attempts by the US and its liberal democratic allies in Asia to coerce China and by EU and NATO members to coerce Russia. Shared values talk can also be used to discipline wayward allies who are supposed to be committed to the political principles in question. EU leaders and some of Washington's NATO allies have sought to place such pressure on the Trump Administration. Participating in shared values talk may also be self-coercive. But if values talk is to be an effective form of coercion, it must impose costs that the target deems important.

Keywords: Values; coercion; power; allies; adversaries; propaganda.

\section{Introduction}

Quests for shared values can be politically divisive. The champion of values pluralism once warned that: 
'values can clash - that is why civilisations are incompatible. They can be incompatible between cultures, or groups in the same culture, or between you and me. We can discuss each other's point of view, we can try to reach common ground but in the end what you pursue may not be reconcilable with the ends to which I find that I have dedicated my life.' (Berlin, 1988, 10).

In international politics, that common ground is especially elusive in parts of the world marked by ideological diversity. This includes Asia where the United States damaged its position in the 1980s by insisting that the liberal values many western societies hold dear were universally applicable. This proposition angered some of America's close regional partners including Singapore which made a counter-claim for Asian values, a problematic idea itself given the region's many values systems. One chronicler of this angry debate argues that: 'in any society, some individuals are likely to value order and fear disorder more than others do. It follows that such order-valuing, disorder fearing people may constitute a higher proportion of the citizenry of one society compared with another.' (Emmerson, 1995, 95).

Compromises or bargains on values may be very hard to achieve in these settings. In another study focusing on Asia's recent experience, Buszynksi (2004, 1) argues that threats to values and identity 'arouse the deepest passions'. As a consequence, they 'cannot be compromised, negotiated or traded.' If agreement is to be found, it may be nothing more than the accommodation of different approaches. Hence Acharya $(2016,14)$ suggests that any plans for a security 
community in Asia need to come to terms with the region's 'tradition of ideological pluralism and tolerance.'

As a result, hopes for cooperation depend on a willingness to look past differences in values, especially when these apply to the running of domestic politics. Lee and Lee $(2016,300)$ have argued that to the extent that they are willing to countenance cooperation which requires any agreement on liberal political norms, Southeast Asian governments are much more comfortable with 'groupings or principles that promote elements of an external liberal regional order' than those that focus on democratic domestic practices. This sensitivity is even more evident for Northeast Asia's largest polity. Zhongping and Jing (2014, 8) argue that for Chinese policymakers a strategic partnership 'transcends differences in ideology and social system' and is made possible when the parties instead 'endeavour to expand converging interests.'

It should not be thought that liberal democracies are inherently unable or unwilling to sacrifice the high moral ground on values for the sake of a promising partnership. In 2015 the Obama Administration agreed to a joint statement with the visiting Vietnamese Prime Minister calling for stronger links between the two countries, one the world's leading liberal democracy, the other a one-party state. As Thayer (2015) explains,

'Obama and Trong agreed to pursue "a deepened, sustained, and substantive relationship on the basis of respect for each other's political systems, independence, sovereignty and territorial integrity." These words are important because ideological conservatives in Vietnam voice 
suspicions that the United States wants to overturn Vietnam's socialist regime through "peaceful evolution".'

The prize for accommodating non-liberal values systems in recent American foreign policy should not go to the Obama Administration, but to its successor. Donald Trump has elevated tensions with America's liberal allies and partners by seeking closer friendships with authoritarian regimes and leaders. A widely noticed attempt to explain this approach came from the Trump Administration's first (and short-lived) Secretary of State. Addressing State Department colleagues in 2017, Rex Tillerson (2017) observed that 'guiding all of our foreign policy actions are our fundamental values: our values around freedom, human dignity, the way people are treated.' But then he added a significant rider: 'in some circumstances, if you condition our national security efforts on someone adopting our values, we probably can't achieve our national security goals or our national security interests. If we condition too heavily that others must adopt this value that we've come to over a long history of our own, it really creates obstacles to our ability to advance our national security interests, our economic interests.'

Tillerson was not the first American to wonder about these things. There is a long history of arguing against values-based foreign policies. One of the main architects of US Cold War foreign policy argued against imposing 'values, traditions, and habits of thought on peoples for whom these things have no validity and no usefulness.' (Kennan, 1977, 43) In the optimistic years of the early post-Cold War period, Michael Mandelbaum (1996) warned that values- 
based foreign policies often lead governments into unwise expeditions which can be avoided by dispassionate calculations of national interest. One of his chief opponents in this debate was himself on record in raising important caveats: 'If we insist that the only kind of law we want is the law which results from the promotion of our values', Stanley Hoffmann $(1959,242)$ had argued early in the Cold War, 'then we will be condemned to stay in chaos now in the hope of reaching Eden in a most vaguely determined future.'1

One might be tempted to conclude that liberal democracies should wake up to the fact that a focus on shared values can lead to unwanted divisions in international relations. This logic only works, however, if we assume that liberal polities always see these divisions as unwanted and counterproductive. A quite different logic may apply when liberal polities do not wish to cooperate with illiberal regimes. If their desire is for more competitive relationships, the divisive potential of the quest for common values may then become politically useful.

This deliberately adversarial feature of claims to shared values is the focus of the argument presented below. Commitments to shared values, it will be suggested, offer a potent combination of coordinating power and competitive power. Liberal polities often coordinate around statements of shared values which serve as signs of commitment to the group. But at the same time these statements of shared principles can be used to isolate and vilify countries beyond the group.

\footnotetext{
${ }^{1}$ Elsewhere, and even more pessimistically, Hoffmann $(1963,526)$ argued that 'common values have not in the past always prevented the slaughter of peoples that were divided into separate political units.'
} 
Values coordination can therefore offer competitive advantages. Somewhat ironically, this is especially the case when claims are being made that the values in question are universally applicable.

\section{The Nature of Values}

Before setting this proposition about the power of shared values claims in a theoretical context, some understanding of values is required. This is not a straightforward matter: van Deth and Scarbrough $(1995,23)$ cite one German study which identified 'no less than 180 different definitions' of the term. But amidst all of the contestation these two authors still manage to provide a general and helpful definition: 'values are non-empirical - that is, not directly observable - conceptions of the desirable, used in moral discourse, with a particular relevance for behaviour.' (van Deth and Scarbrough, 1995, 22).

Each one of the three elements of this definition deserve close scrutiny. The argument that values are 'conceptions of the desirable, used in moral discourse' draws attention to values as ideas about what life should be about. This is not a consensus view. In the quest for a 'scientifically fruitful' conceptualisation, some scholars, including Rokeach $(1973,5)$, have sought to remove notions of the desirable in defining values. But it seems almost inescapable that issues of moral desirability enter into our conception of values. As Neal $(1964,75)$ argued over a half century ago, 'Values refer to widely-shared conceptions of the good: societal values...to conceptions of the good society'. 
This moral dimension is doubly relevant to the present study. In the first instance, many of the claims to shared values discussed in this article have been made by groups of liberal democracies which present themselves as guardians of morally significant political ideas. The freedoms of opinion, assembly, and speech, and other human rights, invoke obvious moral dimensions, as do the ideas of representative democracy and the rule of law. These political values are not desirable simply because they are politically effective or necessary. They are desirable because they are seen to be good. In the second instance, those who advertise their commitment to (moral) values in international politics may use the high moral ground they have staked out for themselves as a power advantage over others. These moral claims can be strategically advantageous, even if we don't think the arena of strategic relationships supports morally sensitive conduct.

This leaves the other elements of van Deth and Scarbrough's definition, both of which are potentially problematic. While it seems sensible to claim that values have a 'particular relevance for behaviour' it is very hard to know what this relationship between values and behaviour actually is. It is not unusual for leaders of liberal democracies to explain their decision-making on the basis of their society's values. But it is very difficult to know quite how much the values in question are actually responsible for their decisions.

One example of this problem comes from New Zealand security policy. In announcing his country's commitment to join an Australian-led training mission in Iraq, (then) Prime Minister John Key (2015) said that: 
'New Zealand is a country that stands up for its values. We stand up for what's right. We have an obligation to support stability and the rule of law internationally. We do not shy away from taking our share of the burden when the international rules-based system is threatened. We have carved out our own independent foreign policy over decades and we take pride in it. We do what is in New Zealand's best interests. It is in that context that I am announcing that the Government has decided to take further steps to help the fight against ISIL.'

The problem here was not so much whether judgements about values were in any way relevant. It is whether other considerations, including New Zealand's prioritization of its security relationships with Australia and the United States, were more decisive. This ubiquitous mixed motive problem can make it hard to assess how important values considerations are to foreign policy decisionmaking. As van Deth and Scarbrough $(1995,31)$ argue, values 'need to be tied in with a much larger array of ideas, beliefs, concepts, understandings before they can have effects for action.'

The third and remaining element of their definition of values is also potentially troubling. If values are not 'directly observable,' how can it be known when - and if - they are in play? How then can we know whether or not values can be a source of power, coercive or otherwise? This is doubly difficult if we have established that the relationship between values and behaviour is important but undetermined. But one thing is very observable. As the quote from John Key confirms, governments do make statements about values they claim to hold dear. 
These claims about values are observable. The present study does not argue that values themselves (which are not easily observable) have coercive power. It argues that states and their leaders use observable (and often audible!) public statements about shared values in attempts to influence others.

There are still going to be objections to be dealt with. What happens if the Emperor has no clothes? What if the state making a claim that it shares certain values behaves very obviously in a way that betrays that claim? But this is not an insurmountable problem. Inconsistencies of this sort are not new to the study of coercion where governments routinely pretend to be committed to a course of action that they are very unlikely, and even physically unable, to undertake. North Korea's nuclear coercion, including repeated threats to respond to United States and South Korean exercises as an act of war, is an obvious case in point. Likewise, as Goldsmith and Posner $(2006,6)$ indicate, talk about shared values might still be used to shape the expectations and behaviour of other actors even when it does not accurately reflect the political actions of those doing the talking.

We might also expect that those governments who talk about shared values do not find themselves in complete agreement on how they prioritise the several values they talk about or what they mean by the values in question (democracy and the rule of law, for example). One of the most prominent critics of Berlin's values pluralism nonetheless admits that:

'we share some of our concepts, including the political concepts, in a different way: they function for us as interpretive concepts. We share them because we share social practices and experiences in which these 
concepts figure. We take the concepts to describe values, but we disagree, sometimes to a marked degree, about what these values are and how they should be expressed.' (Dworkin, 2011, 6).

This lack of complete unanimity is unlikely to be a show stopper for attempts to use shared values talk to influence actors beyond the group. The values talk itself can be an episode in intragroup mythmaking, overlooking discontinuities in the record of values-based cooperation ${ }^{2}$ and presenting instead a vision of longstanding unity. Myths which cover a multitude of sins may still be strategically useful.

\section{Values Power: Coordination and Competition}

It is well recognized that shared values have a unifying role in relations between politically like-minded governments. Common ground on values may lead to all sorts of cooperative possibilities. In his major study of world order, Hurrell $(2007,46)$ argues that:

'Once there is a common identification of, and commitment to, some kind of moral community...with which perceptions of potential common interest can emerge, there may indeed be prudential reasons for the players to cooperate collectively.'

2 Gerald Hensley $(2013,207)$ records that in during a visit to Washington DC at the height of the ANZUS crisis in September 1985 which led to a breakdown in US-NZ security relations, New Zealand's Deputy Prime Minister Geoffrey Palmer told the Reagan Administration that its 'measures were harsh and unreasonable and did not take account of the values and democratic institutions which the two countries shared.' 
Shared values open up prospects for cooperation that might otherwise not be possible. Risse-Kappen $(1997,34)$ observes that 'If liberal democracies form a community, it should affect the identity of the actors and their definition of the national interest.' It follows that if members of this community of values want to draw attention to their commitment to each other, public appeals to their shared values may be a particularly good way of doing so. Goldsmith and Posner (2000, 17) argue that states refer to ideals to indicate those actors with whom they expect to work most closely.

The idea that talk about shared values can be strategically useful in building a sense of community is consistent with the suggestion that: 'The goal of rhetorical practices in collective action is to create solidarity.' (Wendt, 1994, 391). But another term for these rhetorical practices is propaganda, defined by Carr (1949, 132-145) in his famous evaluation of the interwar years as the the power over opinion.' Some years earlier one of the pioneers of the study of propaganda had, argued that:

'Every group has its vested values...An object toward which it is hoped to arouse hostility must be presented as a menace to as many of these values as possible...If the plan is to draw out positive attitudes toward an object, it must be presented, not as a menace and an obstruction, nor as despicable or absurd, but as a protector of our values, a champion of our dreams, and a model of virtue and propriety.' (Lasswell, 1927, 630). 
This is particularly apt for situations where governments are banding together to vilify an outsider (as is the case for the coercive power of shared values). But is the power over opinion really this significant? Can claims about shared values impose or threaten to impose significant costs?

In general terms at least two prerequisites would need to be satisfied. The first is that the targets of this propaganda ought to care about their reputations: ie what others think and say about them. There is some scholarly support on this point. Baldwin $(1985,99)$ argues that because governments are sensitive to ' $t$ ] heir reputations as political actors' they are susceptible to attacks on political symbols. ${ }^{3}$ In a similar vein, Jervis $(1970,6)$ holds that 'a desired image...can often be of greater use than a significant increment of military or economic power. An undesired image can involve costs for which almost no amount of the usual kinds of power can compensate.'

Even if these arguments hold water, a second requirement also needs satisfying: the notion that talk about values is enough to build up and tear down the images of allies and adversaries respectively. Especially in the latter case, (causing harm to reputations) words would need to possess what Schelling $(1966,2)$ called the 'power to hurt.' Coercion is the art of using threats to influence choices (Freedman, 1988, 15) . And words are often used to convey threats, as any

\footnotetext{
${ }^{3}$ Mercer (1996) counsels that governments should not waste time burnishing their reputations because their adversaries or allies will see them through their own predispositions. But he admits that governments believe their reputations are important.
} 
reader of Donald Trump's tweets will know. But does this mean that words themselves have the power to hurt in a significant sense?

Schelling $(1966,150)$ was doubtful on this score: 'words are cheap', he asserted, whereas 'significant actions usually incur some risk or cost.' There are also reasons to wonder if statements about shared values are enough to cement solidarity among partners. Goldsmith and Posner $(2000,19)$ insist that the friendship and loyalty evoked by values rhetoric is only metaphorical.

Much depends here on what we think statements about shared values really involve. On the one hand, even if we think that words communicate a broader message than their surface content suggests, it is still easy to treat them as 'costless signals' (Sartori, 2002, 125). After all, what can be cheaper than saying something? Merely talking about the importance of human rights is far less costly than showing they are important by restraining the powers of the state, for example. On the other hand, it is possible that the articulation of shared values, including in joint statements by governments, constitutes a meaningful ritual. Values talk in international relations might be viewed as a secular political counterpart to religious narratives which 'are often aimed at the creation and maintenance of a people, church, or nation, stressing the moral obligations of loyalty and self-sacrifice for this group above all other groups.' (Graham and Haidt, 2010, 144).

Joining in on language about common values may signal a willingness to bear costs should the group be challenged. Indeed, what could be deemed to be more 
important than the political values dearly held by group members? Values talk often comprises claims about fundamental, and apparently unshakeable, beliefs. And if these beliefs come with expensive implications, they may resemble the costly signalling of religious rituals which Sosis and Bressler (2003) suggest are used by individuals to display their commitment to the group. Values talk may help states bind themselves to commitments that they might otherwise be unwilling to make or keep. They may be the international relations equivalent of a marriage vow made before one's maker. The strategic effect of shared value claims may bring us closer to the married couple whose love for each other 'imposes an additional cost on the affair.' (Frank, 1998, 199).

Words about values may therefore matter more than first appears. In an attempt to question Schelling's doubts on this score, Jervis $(1970,19)$ draws on a communication with Erving Goffman (whose work was an important inspiration for Schelling) to observe that 'words can also be costly, as a gentleman who swears in mixed company soon learns.' This makes values talk something more than cheap talk, which can nonetheless help actors coordinate their expectations and behaviour. (Farrell and Rabin, 1996). It may instead be closer to a costly signal, the second and more ambitious explanation of moral rhetoric mentioned by Goldsmith and Posner (2000).

Governments may underestimate the costs that their values talk involves. They may not realize how much harder they are making it for themselves to jump ship in the future. They may think they are simply engaging in cheap talk, but they be getting closer to costly signalling. In fact their values talk may be self-coercive. 
States which engage in this rhetoric may be narrowing down their options in a future crisis, with less room to avoid cooperating with the community which claims to share these principles. Intentionally or otherwise, governments engaging in shared values talk may be raising their costs of their own defection. Members of a group who each claim to share values may therefore have an additional reason to worry about their own reputations, individually and collectively.

\section{Coercing Adversaries: The Case of China}

If values talk does have the coercive power suggested by the argument above, allies would be expected to use shared values rhetoric to emphasise their unity and then use this values solidarity to criticise and ostracise common adversaries. There should be some evidence of linkages between these coordinating and coercive aspects of shared values talk.

For the United States and several of its liberal democratic allies in Asia, that competitor is China, a trend accentuated during Xi Jingping's leadership. China's challenge to the geopolitical status quo has been especially clear in a series of maritime disputes in East Asia, including in the South China Sea. Accordingly in a 2014 joint statement, the United States and Japan (its leading ally in Asia) argued that China was advancing its claims in the East China Sea and South China Seas 'through the use of intimidation, coercion or force.' (Ministry of Foreign Affairs of Japan, 2014) The same joint statement begins by invoking shared values: 
'The relationship between the United States of America and Japan is founded on mutual trust, a common vision for a rules-based international order, a shared commitment to upholding democratic values and promoting open markets, and deep cultural and people-to-people ties.'

A similar model is evident in joint statements issued by the United States and Australia, the southern anchor in Washington's alliance network in Asia. Following the 2013 "AUSMIN" cabinet level meeting leaders from these two close allies 'reaffirmed their commitment to oppose any coercive or unilateral actions to change the status quo in the East China Sea.' (US Department of State, 2013). Their statement also indicated that Washington and Canberra were 'dedicated to working with China to secure progress on respect for human rights and fundamental freedoms'. Yet this apparent commitment to cooperation with Beijing reflects an "us and them" approach to values.

That sense of bilateral like-mindedness on values is also evident in the growing strategic relationship between Japan and Australia. In 2013, Australia's longserving Foreign Minister Julie Bishop (2013) observed that 'We both champion our shared values of democracy, human rights and the rule of law around the world'. A subsequent joint statement between Japanese and Australian foreign and defence ministers speaks of a 'Special Strategic Partnership between the two countries, founded on common values and strategic interests including democracy, human rights, the rule of law, open markets and free trade.' (Bishop and Payne, 2017). In a clear note of concern about China's approach to maritime territorial disputes with Japan, the 2017 joint statement notes the Ministers' 
'opposition to any unilateral or coercive actions that could alter the status quo or increase tensions in the East China Sea.'

The three allies have also joined in a triangular chorus on these same sentiments, reflected in the statements which are issued from regular meetings of the USAustralia-Japan Trilateral Strategic Dialogue, (TSD). This extended into the early days of the Trump era: the statement following a trilateral meeting of Foreign Ministers in 2017 asserts that this 'partnership, which is founded upon the robust Australia-U.S. and JapanU.S. Alliances, rests on the unshakable foundation of shared interests and values, including a commitment to a rules-based international order, respect for international law, open economies, and the peaceful resolution of disputes.' (US Department of State, 2017).

This demonstrates the use of values arguments to explain coordination within the group. And this coordination extends to criticism of China. The 2017 TSD statement notes that the three 'ministers voiced their strong opposition to coercive unilateral actions that could alter the status quo and increase tensions' in the South China Sea. This is more than a generic commitment to a value which opposes coercion. Being part of this combined language signifies an agreement to ostracise China.

Using shared values talks to criticize and isolate China on maritime issues might seem logical as Beijing has been doing the most to alter Asia's status quo. But 
especially when these efforts bring together the United States and some of its key allies in the region, they are almost the values version of a containment strategy.

This becomes even more credible when larger groups of countries present these values arguments. This includes the repeated quest, led by Japan's (two-time) Prime Minister Shinzo Abe, for a democratic quadrilateral (or diamond) in Asia comprising Japan, the United States, Australia, and India. Tokyo's concern about China has been a central stimulus for these initiatives. In a newspaper article reprising the concept which he had launched in his first Prime Ministerial period, Abe (2012) noted his fears that 'the South China Sea seems set to become a "Lake Beijing." ' He concluded by claiming that

'to improve Sino-Japanese relations, Japan must first anchor its ties on the other side of the Pacific; for, at the end of the day, Japan's diplomacy must always be rooted in democracy, the rule of law, and respect for human rights.'

The idea that democratic unity is a response to China's growing influence suggests that common values can be an antidote to Beijing's coercion which, as Lee and Lee $(2016,285,287)$ note, is central to Abe's criticism of Beijing. Green and Twining $(2008,6)$ argue that Japan's leaders began to emphasise democratic unity with the United States as they became conscious of their country's relative weakness vis-à-vis China.

As Japan has generally been unhappy when there are signs of closer US-China collaboration, (because of the risk that Japan is left out in the cold), it would have 
been counterproductive for Tokyo to criticize China for something Beijing might easily have been able to correct. For China to come close to satisfying liberal values would means an end to the Communist Party of China's political monopoly. That is the very last cost that Beijing's leaders would be willing to pay, not least in an era when 'Beijing has banned academic research and teaching on ...universal values, civil society, citizens' rights, freedom of the press', and 'the independence of the judiciary'. (Economy, 2014, 83). Hence a unified attack on China's lack of democratic credentials doesn't just vilify Beijing. It politically excludes Beijing as a legitimate actor. And this repeated values coercion reinforces the message that the liberal democracies ought to lead.

If this is part of the intention behind the quadrilateral concept, in practice the result has been less definitive. Even the holding of formal quadrilateral meetings in 2017 and 2018, commonly on the sidelines of the more inclusive East Asia Summit meetings, has not presented Beijing with an especially firm critique. The readouts from these meetings, which have not yet moved above officials level, seem slightly toothless when compared to the outputs from the TSD. The statement from the mid-2018 meeting between the four countries in Singapore records that attendees:

'reaffirmed shared support for a free, open, and inclusive Indo-Pacific region where all countries respect sovereignty, international law, including with respect to freedom of navigation and overflight, and sustainable development. The officials confirmed that the four countries had a common commitment, founded on shared democratic values and 
principles, to uphold and strengthen the rules-based order in the IndoPacific.' (US Department of State, 2018).

Some of the ingredients for a values-based coercion attempt may be found here including the emphasis on democracy. And it is not too much of a stretch to suggest that the four have China in mind in emphasizing freedoms of navigation and overflight. But the pushback in the statement, such that it exists, is fairly gentle. Given China's previous concerns about the quadrilateral idea as tantamount to an effort at containment, the very fact that these meetings are taking place may be at least as significant as any statement they produce. But as O'Neil and West (2019) suggest, there probably is not very much in the latest quadrilateral developments for Beijing to get excited about. Including India may make Abe's quadrilateral a reality in form. But in substance, as Bisley (2018) argues, New Delhi's lesser attachment to the geopolitical worries motivating the other three has had a diluting effect.

\section{Coercing Russia Through Values Talk Too}

Attempts to form wider groupings of states using their democratic credentials to coerce non-democracies do not stop here. Ambitions of this sort appear to have played a role in the proposals made more than a decade ago in the United States for a Concert of Democracies. Ian Clark $(2009,577)$ has observed that these arguments emerged just as concerns were growing that Russia and China were benefitting from autocracy's rising international appeal. 
But did this necessarily mean that values arguments were being used competitively (let alone coercively?). Ikenberry and Slaughter, $(2006,9)$ among the main proponents of the Concert idea, insisted that 'America's goal should not be to block or contain China, but rather to help it achieve its legitimate ambitions within the current international order and to become a responsible stakeholder in Asian and international politics.' Yet, they also suggested that America's dominant security role in Asia could 'foster conditions within which China will increasingly make choices to embrace liberty under law.' (Ikenberry and Slaughter, 2006, 49).

The divisive potentials in this proposal were never far away. Alessandri $[2008$, 85) observes that

'a Concert of Democracies would divide the United States' alleged rivals. India and Brazil would qualify for membership in the new organisation. Russia and China, instead, would be isolated within the international system.'

Agreement on this point comes from some the concept's main supporters. Daalder and Lindsay $(2007,12)$ asserted that 'What the exclusion of authoritarian regimes means is that the Concert will stand in opposition to their political systems.' This confirms the view that democracy 'is prone to manifest itself as a form of exclusion, even when international society might have a preference for inclusion.' (Clark, 2009, 563). 
As divisive as these ideas may seem, the concert of democracies has never got beyond proposal stage. But it might be suggested that a democratic concert already existed in the main organisations for European and Atlantic security cooperation. These groupings have liberal values written into their founding documents. Explicit commitments to democratic values are part of NATO's DNA. The preamble to the 1949 Atlantic Treaty reflects the commitment of members 'to safeguard the freedom, common heritage and civilisation of their peoples, founded on the principles of democracy, individual liberty and the rule of law.' Similarly, as Manners $(2002,241)$ explains, 'The EU is founded on and has as its foreign and development policy objectives the consolidation of democracy, rule of law, and respect for human rights and fundamental freedoms.'

Great power Russia has provided an ideal target for extending this values-based collaboration in the $21^{\text {st }}$ century. Vladimir Putin's actions have have provided NATO and the EU with a model example of what a commitment to democratic values does not look like. On the one hand, Putin's vision for an Eurasian Union promotes a view of citizen-state relations which directly challenges European liberal values. On the other hand, Russia's annexation of Crimea, pressure on Ukraine, and threats to NATO members all challenge European security interests.

These circumstances have been ripe for talk about competing values systems. Speaking at the UK parliament in 2016, the Deputy head of NATO argued that 'our whole system of European security...is being challenged by a revisionist, revanchist Russia.' The answer, Alexander Vershbow said, was to be 'strong on 
liberal, democratic values; and strong on defence and deterrence to protect those values.' (NATO, 2016).

Of course it is one thing to emphasise deterrence, itself a leading variety of coercion, to advance a group's values. It is another thing to deploy these values as part of the coercive effort. But some of the values talk in Europe's relations with Putin's Russia hint at this ambition. Speaking before a meeting with Barack Obama in 2017, EU President Donald Tusk portrayed Russia as one of the main actors (alongside Islamic State) which was challenging the unity of the Europe and the United States by:

'attacking our fundamental values, freedom, prosperity, liberal democracy and geopolitical order. Our adversaries with the use of propaganda, acts of violence, violation of the sovereignty of our neighbours are determined to weaken the foundations of the political community of the Western world.' (European Council, 2015).

This depiction of Russia as a political wrecking ball, hostile to Western values, stands in contrast to the EU's perception of itself as an institution builder. A group of countries can project the image of military unity to reassure members and coerce adversaries. But it can also present a picture of values unity for similar purposes, especially when the group believes its own values are the superior ones. Tusk (2017) subsequently observed that 'Today's world is full of barbarians, for whom freedom and culture, as we understand them, have become targets to attack.' Hence the values themselves are being threatened. His answer stays within the same idiom: the countries of Europe 'must once again define our 
territory, not geographically, but in a civilizational, cultural, and perhaps even symbolic sense'. (Tusk, 2017).

This combined picture of Russian threat and European unity neatly coincides with Lasswell's protector-menace dichotomy. Tusk connects the two: the precious values unity of Europe, the protector, against the vicious values from Russia, the menace. Moreover the common values which Europe represents are not just any set of common values. They are values that authoritarian countries like Russia cannot be expected to share. Bok $(1995,76-80)$ may be correct that there are certain minimal values which are held more or less universally and which can allow for inclusive forms of international cooperation. She even cites a comment from Isaiah Berlin in support of this position. But these European values are not minimal universal ones. ${ }^{4}$ They often require governments to make somewhat costly choices to join the group that says it shares them. If governments emphasise minimal values in their shared values talk they may allow room for cooperating with outsiders. This is closer to the values pluralism advocated by Acharya. But when they emphasise maximal values, as has happened here, they close that door. Values coercion is not just about public displays of values agreements: it is about knowing which values buttons to push.

\section{Coercing Allies}

\footnotetext{
4 The minimal values Bok $(1995,15)$ has in mind include 'injunctions against violence, deceit and betrayal'.
} 
Agreements on values are not just useful for coercing adversaries. They can also be used to bring allies to heel. This may go against the grain for relations between ideational allies. Daalder and Lindsay $(2007,10)$ attest that 'There is no place for intimidation or coercion in inter-democratic interactions.' Nonetheless expectations that allies should act according to common values can be used to discipline a close partner. Speaking in Jerusalem at the funeral of Shimon Peres, Barack Obama (2016) offered two explanations for the close bilateral cooperation enjoyed by the United States and Israel. First came an acknowledgement that against a backdrop of tensions in the Middle East, 'these bonds encompass common interests -- vital cooperation that makes both our nations more secure.' Second, Obama moved to a more inspiring and emotional rationale:

'But today we are reminded that the bonds which matter most run deeper. Anchored in a Judeo-Christian tradition, we believe in the irreducible value of every human being. Our nations were built on that idea. They were built in large part by stubborn idealists and striving immigrants, including those who had fled war and fled oppression. Both our nations have flaws that we have not always fixed, corners of our history which date back to our founding that we do not always squarely address. But because our founders planted not just flags in the eternal soil, but also planted the seeds of democracy, we have the ability to always pursue a better world. We have the capacity to do what is right.'

Obama appeared to be signalling to Benyamin Netanyahu, the incumbent Prime Minister, that these were values that America expected Israel would stand by, 
and which Washington was worried that Israel was walking away from. There was a cost implied if Israel did not live up to these values: a reduced status in the eyes of its single-most important partner, and the potential that America's support for Israel might be increasingly conditional.

With Donald Trump's election victory, this sort of values pressure in the Middle East immediately became much less likely. Instead the values shoe was quickly transferred to the other foot. Some of America's long-standing allies became concerned that the incoming Administration would be hostile to the liberal values that had long featured in American foreign policy. As Mr Trump was basking in the glow of his electoral success, Angela Merkel (2016) outlined the principles she hoped would continue to guide Washington's approach to domestic and international politics. 'Germany and America', her statement read, 'are bound by common values - democracy, freedom, as well as respect for the rule of law and the dignity of each and every person, regardless of their origin, skin color, creed, gender, sexual orientation, or political views. It is based on these values that I wish to offer close cooperation, both with me personally and between our countries' governments.'

As a report in one leading newspaper indicated, this was no more than qualified congratulation. (Faiola, 2016). Merkel appeared to be signalling that if President Trump's Administration failed to live up to those common values, cooperation between the United States and Germany (and possibly Europe) would suffer. This was as much a message of warning as of hope. 
Similar messages were conveyed by other European and Atlantic leaders, confirming the role of values claims as coordinated instruments of pressure. A media report noted that in keeping with Merkel's comments, France's President Hollande had 'urged Trump to "respect principles", which he also listed: "democracy, freedoms, and the respect of every individual".' (Rettman and Kirk, 2016).

The early months of Trump's Presidency confirmed a number of these European concerns. There was almost a sense that Europe had lost its values partner and needed to round its own wagons. At an EU Summit in February 2017, Federica Mogherini, the European Commission's high representative, was quoted as saying that 'We are and we will remain friends with the American people and the American administration on the basis of our own strong values, principles and interests.' (Boffey, 2017).

Values talk had almost become a way of declaring independence from the erstwhile leader of the western values community. Five months after Mr Trump's inauguration, Canada's Foreign Minister Chrystia Freeland (2017) observed that as 'our friend and ally has come to question the very worth of its mantle of global leadership' Canada needed to step into the void so that 'more of the world shares Canadian values. Those values include feminism, and the promotion of the rights of women and girls.' A clearer message of criticism regarding Trump's priorities could hardly have been made. And while Freeland referred specifically to Canadian values, the sense of solidarity with transatlantic and NATO allies in Europe was very clear. As a New York Times article suggested, there were strong 
parallels between Canada's evolving posture and Merkel's comments 'that European countries should "really take our fate into our own hands".' (Austen, 2017).

\section{Conclusion: Does Values Talk Have Coercive Power?}

The connection between values and coercion may remain problematic for some readers, including for some who nonetheless regard values as a source of power. In his influential work on soft power, Joseph Nye has argued that America's political principles can be a source of meaningful influence internationally. But this is achieved not by the power to hurt but by the power to attract. Instead Nye $(2008,94)$ argues that 'soft power is the ability to affect others to obtain the outcomes one wants through attraction rather than coercion or payment.' Yet as the present article has shown, we have good reasons to think that states are using claims about their values systems, and about the values systems they share with each other, to exert coercive pressure on other governments.

But are these attempts effective? As Byman and Waxman (2002, 33-7) indicate, more than one variable is involved when we come to consider whether any act of coercion can be deemed a success. But one of the most crucial factors is the target's estimation of the costs they face from the threat that has been levelled at them. A necessary, but by no means sufficient, condition for effective coercion is a belief by the target that the costs of undertaking unwanted action, or of not undertaking desired action, are too high. Understanding whether values talk can coerce means understanding the costs it threatens to impose. For the most part, 
military coercion threatens the target's security. Economic coercion threatens the target's prosperity. Coercion involving the power over opinion threatens to impose different costs.

One of the costs from propaganda might well be an actor's international legitimacy. This is suggested in the literature on the Democratic Concert idea. Clark $(2009,571)$ concludes that the proposed Concert is an attempted 'transmutation of a principle of domestic legitimacy into a principle of international legitimacy.' Alessandri $(2008,73)$ argues that the proposals for a Democratic Concert reflect 'the belief that democracy is a superior principle of international legitimacy and provides the most solid foundation for international order.' And Daalder and Lindsay $(2007,11)$ assert that the Concert of Democracies would enjoy unique legitimacy because 'Democracies understand that international peace and justice in an era of global politics rest on protecting the rights of individuals'.

This is then played back against the offending illiberal regimes. Nye (1990: 167) suggests that 'If a state can make its power seem legitimate in the eyes of others, it will encounter less resistance to its ideas.' But the reverse applies here: if a state holds to political ideas that are bound to generate resistance, it will forfeit its legitimacy in the eyes of others.

Yet it needs to be wondered whether this sort of legitimacy matters to these illiberal targets? The values talk by NATO and EU members in regard to Russia, and by the United States and some of its Asian allies in regard to China, may seek 
to dent the legitimacy of Moscow and Beijing respectively. But is there any evidence that Putin holds dear Russia's legitimacy in terms of the values emphasized by western democracies? In fact, if Russia's leader gains domestically by being seen to resist the influence of international liberal opinion, Moscow may be less vulnerable to coercive values talk than many European and North American capitals might hope.

Xi Jinping may give the appearance of being especially sensitive about China's international status as a rising power. But this is not the same thing as legitimacy defined in terms of liberal values. Xi may be banking on a different source of legitimacy: one that comes from China's undoubted economic success. This alternative legitimacy may in fact be used to affirm non-democratic politics. After all, China is the leading example of the argument that autocracies can be prosperous.

When it comes to the attempts by NATO and EU leaders to use values talk to coerce a wayward ally, uncertainties also apply. These efforts will be ineffective if President Trump does not hold America's democratic reputation in high esteem. He does not appear beholden to the view from a leading opponent that 'Only our democratic values define us.' (Biden, 2017). In this situation, the coercive power of shared values is blunted, unless values talk from America's allies has an important secondary influence on other US policymakers and opinion-makers. 
In fact traditional allies will wonder if the reduction in Washington's rhetorical commitment to shared values during the Trump era signals a reduced commitment to values solidarity. That would be a reasonable conclusion to draw from the $45^{\text {th }}$ President's address to the United Nations General Assembly in September 2018 when he observed that:

'Each of us here today is the emissary of a distinct culture, a rich history, and a people bound together by ties of memory, tradition, and the values that make our homelands like nowhere else on Earth...I honor the right of every nation in this room to pursue its own customs, beliefs, and traditions. The United States will not tell you how to live or work or worship.' (Trump, 2018)

In the same address President Trump did praise the belief of his fellow citizens in 'the majesty of freedom and the dignity of the individual...self-government and the rule of law.' But these values were presented as patriotic, independent, and American conceptions of the desirable. Trump did not advertise these as shared values which bound the US to its traditional liberal democratic partners.

Concerns amongst allies about Washington's defection from cooperation under Mr Trump are now so routine as to be hardly noteworthy. And it is only logical that the Trump Administration should seek to lower the costs to itself that comes from that defection. One way of doing that is to speak less of shared values with partners who have come to depend on American military and economic power. 


\section{References}

Abe, S., 2012. “Asia's Democratic Security Diamond.” Project Syndicate, 27

December. https://www.projectsyndicate.org/commentary/a-strategic-

alliance-for-japan-and-india-

by-shinzo-abe.

Acharya, A., 2016. "Security Pluralism in the Asia-Pacific: Reshaping Regional Order." Global Asia 11(1): 12-17.

Alessandri, E., 2008. “World Order Re-founded: The Idea of a Concert of Democracies." The International Spectator 43 (1): 73-90.

Austen, I. 2017 “A Canada Minister’s Speech Shows Growing Divide With the U.S." The New York Times, 12 June.

https://www.nytimes.com/2017/06/12/world/americas/a-canadianministers-speech-shows-a-growing-divide-with-the-us.html?mcubz=1\&_r=0;

Australian Department of Defence, 2016. Defence White Paper 2016. Canberra: Commonwealth of Australia.

Baldwin, D., 1985. Economic Statecraft. Princeton: Princeton University Press. 
Berlin, I., 1988. “The Pursuit of the Ideal.” in Hardy, H. and Hausheer, R. (eds.), The Proper Study of Mankind. London: Chatto \& Windus: 1-16.

Biden, J., 2017. “Reclaiming America's Values.” The New York Times, 14 September. https://www.nytimes.com/2017/09/14/opinion/joe-biden-moreperfect-union.html?mcubz=1\&_r=0; .

Bishop, J. 2013. “Address to 2013 Japan Update.” Canberra, Australia, 5 November. http://foreignminister.gov.au/speeches/Pages/ 2013/jb_sp_131105.aspx? ministerid=4;

Bishop, J., and Payne, M., 2017. “Joint Statement: Seventh Japan-Australia 2+2 Foreign and Defence Ministerial Consultations". Australian Government, Department of Defence, 20, 21 April. https://www.minister.defence.gov.au/minister/marisepayne/statements/joint-statement-seventh-japan-australia-22foreign-and-defence.

Bisley, N., 2018. "Is there a problem with...the Quad?" China Matters, July. http://chinamatters.org.au/public-outreach/policy-brief-july/

Boffey, D., 2017. "François Hollande leads attack on Donald Trump at EU Summit." The Guardian, 3 February. https://www.theguardian.com/ world/2017/feb/03/francois-hollande-attacks-donald-trump-eu-summit. 
Buszynski, L., 2004. Asia-Pacific Security - Values and Identity. New York:

Routledge Curzon.

Byman, D., and Waxman, M., 2002. Dynamics of Coercion: American Foreign Policy and the Limits of Military Might. New York: Cambridge University Press.

Carr, E., 1949. The Twenty Years' Crisis, 1919-1939: An Introduction to the Study of International Relations. London: Macmillan.

Clark, I., 2009. “Democracy in International Society: Promotion or Exclusion?” Millenium 37 (3): 563-581.

Daadler, I., and Lindsay, J., 2007. “Democracies of the World, Unite” The American Interest 2 (3): 5-19.

Dworkin, D., 2011. Justice for Hedgehogs. Cambridge MA: Belknap Press.

Economy, E., 2014. “China’s Imperial President: Xi Tightens His Grip.” Foreign Affairs 93 (6): 80-91.

Emmerson, D., 1995. “Singapore and the Asian Values Debate.” Journal of Democracy 6 (4): 95-105.

European Council, 2015. “Statement by President Donald Tusk before his meeting with President Barack Obama in Washington". 9 March 
http://www.consilium.europa.eu/en/press/press-releases/2015/03/150309statement-tusk-before-meeting-obama-washington/.

Faiola, A., 2016. "Angela Merkel congratulates Donald Trump - kind of." The Washington Post, 9 November. https://www.washingtonpost.com/news/ worldviews/wp/2016/11/09/angela-merkel-congratulates-donald-trumpkind-of/?utm_term=.ed1079d2c90.

Farrell, J., and Rabin, M., 1996. “Cheap Talk.” The Journal of Economic Perspectives 10 (3): 103-118.

Frank, R., 1998. Passions Within Reason: The Strategic Role of the Emotions. New York: W.W. Norton.

Freedman, L., 1998. "Strategic Coercion” in Freedman, L., (ed.), Strategic Coercion: Concepts and Cases. Oxford: Oxford University Press: 15-36.

Freeland, C., 2017. “Address by Minister Freeland on Canada's Foreign Policy Priorities" Ottawa, 6 June https://www.canada.ca/en/global affairs/news/2017/06/address_by_ministerfreelandoncanadasforeignpolicyprio rities.html.

Goldsmith, J., and Posner, E., 2000. Moral and Legal Rhetoric in International Relations: A Rational Choice Perspective. Working Paper 108. University of Chicago: John M. Olin Program in Law and Economics. 
Graham, J., and Haidt, J., 2010. “Beyond Beliefs: Religions Bind Individuals into Moral Communities" Personality and Social Psychology Review 14 (1): 140-150.

Green, M., and Twining, D., 2008. “Democracy and American Grand Strategy in Asia: The Realist Principles Behind an Enduring Idealism". Contemporary Southeast Asia 30 (1): 1-28.

Gyngell, A., and Wesley, M., 2007. Making Australian Foreign Policy, 2nd ed. Cambridge; New York: Cambridge University Press.

Hensley, G., 2013. Friendly Fire: Nuclear Politics and the Collapse of ANZUS, 19841987 Auckland: Auckland University Press.

Hoffmann, S., 1959. "Implementation of International Instruments on Human Rights" Proceedings of the American Society of International Law at Its Annual Meeting 53: 235-245.

Hoffmann, S., 1963. “Discord in community.” International Organization 17 (3): 521-549.

Hurrell, A., 2007. On Global Order: Power, Values and the Constitution of International Society. Oxford: Oxford University Press. 
Ikenberry, G., 2017. "The Plot Against American Foreign Policy." Foreign Affairs $76(3): 2-9$.

Ikenberry, G., and Slaughter, A., 2006. Fostering a World of Liberty Under Law: US National Security in the $21^{\text {st }}$ Century, Final Report of the Princeton Project on National Security. Princeton NJ: The Woodrow Wilson School of Public and International Affairs, Princeton University.

Jervis, R., 1970. The Logic of Images in International Relations. Princeton: Princeton University Press.

Kennan, G., 1977. The Cloud of Danger: Current Realities of American Foreign Policy. Toronto: Atlantic-Little.

Key, J., 2015. “Prime Minister's Ministerial Statement on ISIL.” Wellington, 25 February http://www.beehive.govt.nz/speech/prime-minister\%E2\%80\%99sministerial-statement-isil.

Lasswell, H., 1927. “The Theory of Political Propaganda.” American Political Science Review 21 (3): 627-631.

Lee, L., and Lee, J., 2016. “Japan-India Cooperation and Abe’s Democratic Security Diamond: Possibilities, Limitations and the View from Southeast Asia." Contemporary Southeast Asia 38 (2): 284-308. 
Mandelbaum, M. 1996. “Foreign Policy as Social Work.” Foreign Affairs 75 (1): 16-32.

Manners, I., 2002. “Normative power Europe: a contradiction in terms?” Journal of Common Market Studies 40 (2): 235-258.

Mercer, J., 1996. Reputation and International Politics. Ithaca: Cornell University Press.

Merkel, A., 2016. "Press statement by Federal Chancellor Angela Merkel on the outcome of the US presidential election." Berlin, 9 November; https://archiv.bundesregierung.de/archiv-de/meta/startseite/press-statementby-federal-chancellor-angela-merkel-on-9-november-2016-on-the-outcome-ofthe-us-presidential-election-844280.

Ministry of Foreign Affairs of Japan, 2014. “U.S.-Japan Joint Statement: The United States and Japan: Shaping the Future of the Asia-Pacific and Beyond." 25 April; http://www.mofa.go.jp/na/na1/us/page24e000045.html.

Morgenthau, H., 1975. Politics Among Nations: The Struggle for Power and Peace. $5^{\text {th }}$ ed. New York: Alfred A. Knopf.

NATO, 2016. “Strong on Values, Strong on Defence: NATO’s Role in Projecting Stability to the East and South." Speech by NATO Deputy Secretary General 
Alexander Vershbow at the Henry Jackson Society (UK Houses of Parliament), 23

May; http://www.nato.int/cps/en/natohq/opinions_131446.htm? selected

Locale=en.

Neal, M., 1964. "Methodology for the Examination of the Function of Values and Interests in the Process of Social Change." Sociological Analysis 25 (2): 75-90.

Nye, J., 1990. “Soft Power.” Foreign Policy. 80: 153-171.

Nye, J., 2008. "Public Diplomacy and Soft Power." Annals of the American Academy of Political and Social Science 616: 94-109.

Obama, B., 2016. "Remarks by President Obama at Memorial Service for Former Israeli President Shimon Peres." Mt Herzl, Jerusalem, 30 September. https://www.whitehouse.gov/the-press-office/2016/09/30/remarkspresident-obama-memorial-service-former-israeli-president-shimon.

O’Neil, A., and West, L., 2019. “Why the Quad won't ever be an Asian NATO.” The Strategist, 24 January. https://www.aspistrategist.org.au/why-the-quad-wontever-be-an-asian-nato/

Rettman, A., and Kirk, L., 2016. "Merkel urges Trump to respect 'values'." EUobserver, 10 November. https://euobserver.com/foreign/135859. 
Risse-Kappen, T., 1997. Cooperation Among Democracies: The European Influence on U.S. Foreign Policy. Princeton: Princeton University Press.

Rokeach, M., 1973. The Nature of Human Values. New York: The Free Press.

Sartori, A., 2002. "The Might of the Pen: A Reputational Theory of Communication in International Disputes." International Organization 56 (1): 121-149.

Schelling, T., 1966. Arms and Influence. New Haven: Yale University Press.

Slaughter, A., 2011. “Interests vs. Values? Misunderstanding Obama’s Libya Strategy." New York Review of Books, 30 March.

http://www.nybooks.com/daily/2011/03/30/interests-values obamas-libya-strategy/.

Sosis, R., and Bressler, E., 2003. “Cooperation and commune longevity: A test of the costly signaling theory of religion." Cross-cultural Research 37 (2): 211-239.

Thayer, C., 2015. “Developments in US-Vietnam Relations Show Emerging Partnership." The Diplomat, 13 July. http://thediplomat.com/2015 /07/8-developments-in-us-vietnam-relations-show-emerging-partnership/ 
Tillerson, R., 2017. “Remarks to U.S. Department of State Employees.”

Washington D.C., 3 May; https://www.state.gov/secretary/20172018

tillerson/remarks/2017/05/270620.htm.

Trump, D., 2018. "Remarks by President Trump to the $73^{\text {rd }}$ Session of the United Nations General Assembly." New York, 25 September.

https://www.whitehouse.gov/briefings-statements/remarks-president-trump73rd-session-united-nations-general-assembly-new-york-ny/.

Tusk, D., 2017. “Europe’s Values are its Best Defense." Project Syndicate, 13 January; https://www.project- syndicate.org/onpoint/europes-values-are-itsbest-defense-by-donald-tusk-2017-01?barrier=accesspaylog.

US Department of State, 2013. “Australia-United States Ministerial Consultations." (AUSMIN) Media Note, Washington DC, 20 November; http://www.state.gov/r/pa/prs/ps/2013/11/217794.htm.

US Department of State, 2017. “Australia-Japan-United States Trilateral Strategic Dialogue Ministerial Joint Statement." Media Note, Washington DC, 6 August; https://www.state.gov/r/pa/prs/ps/2017/08/273216.htm.

US Department of State, 2018. “U.S.-Australia-India-Japan Consultations.” Media Note, Washington DC, 7 June 2018;

https://www.state.gov/r/pa/prs/ps/2018/06/283013.htm

Van Deth, J.. and Scarbrough, E., 1995. "The Concept of Values." in Van 
Deth. J., and Scarbrough, E., (eds.) The Impact of Values: Beliefs in Government, Volume 4. Oxford: Oxford University Press: 21-47.

Van Dyke, V., 1962. "Values and Interests." The American Political Science Review 56 (3): 567-576.

Wendt, A., 1994. “Collective Identity Formation and the International State." The American Political Science Review 88 (2): 384-396.

Zhongping, F. and Jing, H., 2014. “China's strategic partnership diplomacy: engaging with a changing world." Working Paper 8. European Strategic Partnerships Observatory;

http://fride.org/download/WP8_China_strategic_partnership_diplomacy.pdf. 